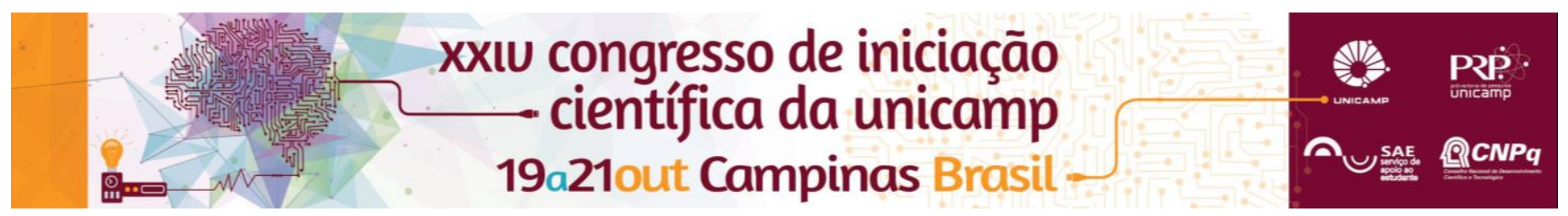

\title{
Co-Habitando com a Fonte nos rituais de Tambor de Mina, Um processo artístico no Método BPI visando construir as bases para uma criação cênica
}

\section{Luiza Tortorella Nogueira Pinto}

\begin{abstract}
Resumo
Este projeto desenvolveu uma pesquisa em dança a partir do Método Bailarino-Pesquisador-Intérprete (BPI) com enfoque em seu eixo Co-Habitar com a Fonte, tendo como núcleo as experiências vivenciadas em pesquisas de campo realizadas em Terreiros de Tambor de Mina das cidades de São Luís-MA e Diadema-SP. Buscou-se uma apreensão sensível dos elementos presentes no referido contexto, posteriormente trabalhados no corpo em Laboratórios Dirigidos e elaborados, por fim, em uma síntese. Conforme o Programa Institucional de Iniciação Científica e o cronograma apresentado no Projeto de Pesquisa, este estudo seria realizado de agosto de 2015 à julho de 2016. No entanto, por motivo de maternidade, houve a necessidade de pedir o cancelamento da bolsa em janeiro de 2016.
\end{abstract}

Palavras-chave:

Método BPI, Co-Habitar com a Fonte, Tambor de Mina

\section{Introdução}

A minha saída do ambiente da sala de aula para entrar em contato direto com as pessoas e as paisagens da manifestação cultural e religiosa do Tambor de Mina, teve nessa pesquisa o seu foco. As experiências vivenciadas em campo, nos terreiros de Mina em São Luís- MA e Diadema- SP, foram registradas em Diários de Campo. Voltando para a sala de aula, esses conteúdos foram trabalhados corporalmente em Laboratórios Dirigidos, os chamados dojos, os quais buscaram deflagrar no corpo elementos tais como imagens, sensações, emoções e movimentos, decorrentes da relação entre os conteúdos encontrados em campo e as minhas próprias peculiaridades e heranças culturais. Esses elementos foram registrados nos Diários de Dojo. Por fim houve uma análise dos registros, buscando-se uma síntese acerca do que foi apreendido em meu corpo. A pesquisa teve de ser interrompida, por motivo de maternidade, no início de 2016, quando aconteceriam Laboratórios Dirigidos mais direcionados, elaborados pela diretora do trabalho (no caso, a orientadora da pesquisa, a Prof ${ }^{-}$Dra. Larissa Sato Turtelli), no sentido de levar a intérprete à nucleação de uma personagem. Apesar de não ter alcançado a estruturação de uma personagem, foi possível desenvolver a estruturação de um corpo - uma modelagem corporal com atributos de sensações, sentimentos, imagens e características de movimento - e organizar uma síntese prática dos principais conteúdos deflagrados em meu corpo.

\section{Resultados e Discussão}

Os resultados do trabalho foram analisados com base nas especificidades do método BPI, enfocando-se principalmente as ferramentas Técnica de Dança do BPI (Estrutura Física e Anatomia Simbólica) e Técnica dos Sentidos ${ }^{1}$. Foi realizado um levantamento acerca das qualidades de movimento mais significativas deflagradas em meu corpo ao final do trabalho, resultando em uma síntese prática e uma síntese teórica acerca do meu desenvolvimento como intérprete no método $\mathrm{BPI}$.

Para a síntese prática, apresentada no encerramento da disciplina Dança do Brasil VI, ministrada pela Prof $^{a}$ Dra. Graziela Rodrigues, elaborei um pequeno roteiro no qual uma mulher partia de sua indiferença - de seu abandono, com movimentos cortados e contidos, com um corpo fechado, carregado de clemência e solidão rumo a uma transformação, à medida que ia encontrando os elementos da natureza em seu caminho, nos quais encontrava confiança, sabedoria e forças, dando fluxo e abertura aos movimentos, que se tornavam mais espiralados e ganhavam uma leveza pendular. Ela ia então preparando uma mistura curativa com as plantas que achava, até tirar de seu próprio corpo o mastro, levando-a ao chão, onde terminava protegendo seu caldeirão e, de certa forma, se transformando também em solo.

\section{Conclusões}

A dramaturgia da dança emergida em meu corpo ao fim do processo se deu na integração dinâmica dos meus próprios aspectos culturais, sociais, fisiológicos e afetivos em diálogo com a expressão encontrada em campo. Assim, a pesquisa me possibilitou alcançar uma organicidade corporal, uma entrega para viver a cena, que não se pautou em representação ou reprodução de formas. Isso me ajudou sobremaneira no meu desenvolvimento como bailarina e intérprete.

\section{Agradecimentos}

Agradeço a Prof ${ }^{\text {a }}$ Dra. Larissa Sato Turtelli, por sua orientação atenta e dedicada, a Prof ${ }^{\text {a }}$ Dra. Graziela Rodrigues, pelos valiosos ensinamentos no método BPI, e ao fomento da Bolsa PIBIC - CNPQ, que possibilitou a realização desta pesquisa.

1 RODRIGUES, G.E.F. As Ferramentas do BPI (Bailarino-PesquisadorIntérprete). In: Anais do I Simpósio e I Congresso Brasileiro de Imagem Corporal (ISBN: 9788599688120). UNICAMP. Campinas, SP. 2010 